\title{
Analysis of Different Rare Metals, Rare Earth Elements, and other Common Metals in Groundwater of South West Bank/Palestine by ICP/MS-Data and Health Aspects
}

\author{
Fuad Al-Rimawi ${ }^{1}$, Khalid Kanan ${ }^{1}$, Mutaz Qutob ${ }^{2,3 *}$ \\ ${ }^{1}$ Faculty of Science and Technology, Al-Quds University, East Jerusalem, Palestine; ${ }^{2}$ Department of Earth and Environmental Stud- \\ ies, Faculty of Science and Technology, Al-Quds University, East Jerusalem, Palestine; ${ }^{3}$ Aquatic and Aquaculture Research Labora- \\ tory, Al-Quds University, East Jerusalem, Palestine. \\ Email: *qutob@planet.edu
}

Received July $15^{\text {th }}, 2013$; revised August $19^{\text {th }}, 2013$; accepted September $23^{\text {rd }}, 2013$

Copyright (C) 2013 Fuad Al-Rimawi et al. This is an open access article distributed under the Creative Commons Attribution License, which permits unrestricted use, distribution, and reproduction in any medium, provided the original work is properly cited.

\begin{abstract}
Ground water samples are collected from south West Bank/Palestine and analyzed for different rare elements $(\mathrm{Rb}, \mathrm{Zr}, \mathrm{U}$, $\mathrm{P}, \mathrm{Ti}, \mathrm{V}$ ), rare earth elements ( $\mathrm{La}, \mathrm{Ce}$, and $\mathrm{Nd}$ ), and other common trace metals ( $\mathrm{Li}, \mathrm{Na}, \mathrm{Mg}, \mathrm{Ca}, \mathrm{Sr}, \mathrm{Ba}, \mathrm{K}, \mathrm{Bi}$ ) that most of them usually have no maximum acceptable limits as either they are considered not to be toxic to human health or there is no sufficient data about their toxicity to human health. This study was conducted to determine the water quality of ground water which is used for drinking in the study area. Water samples from ten groundwater wells were obtained in three different dates of the year (November 2012, March 2013, and April 2013). Three water samples were obtained from each well for each sampling date; so a total of 90 water samples were collected from the ten wells. The results obtained from this study suggest a possible risk to the population of the study area given the high concentration of some metals that have no maximum allowed concentration, and the fact that for many people in the study area, ground water is a main source of their water supply.
\end{abstract}

Keywords: Rare Metals; Rare Earth Elements; WHO Limits; ICP/MS; Ground Water; West Bank

\section{Introduction}

The great importance of water for man makes the accurate management of this natural resource a priority in order to preserve its sustainability. Water analysis plays a decisive role in regulations that determine the water quality levels for specific uses e.g., for drinking water [1]. Water analysis applicability is also extended to the study of water origin and evolution, taking into account the natural and anthropic influences, e.g. water-water and water-rock interactions, groundwater exploitation regulation (protection and recharge of aquifers), contamination processes, etc. It is often assumed that natural ground water from deep wells is clean and healthy [2]. This is usually true with regards to bacteriological composition. However, a large variety of solutes are transferred to the water via complex pathways and processes, such as atmospheric and terrestrial sources. The result is the occurrence of different components in the water, which define the hy-

${ }^{*}$ Corresponding author. drochemical fingerprint. This fingerprint permits identification of water, the media and the interactions between them, including those associated with anthropic activities. The concept is comparable to individual fingerprint identification. High concentrations of many chemical elements can occur in ground water due to variations in the regional geology and water/rock interactions [3-6]. Inorganic chemical quality of ground water is, however, rarely adequately tested before the wells are put into production [7].

Occurrence of trace elements in ground water is very sensitive to geological changes and, in many cases, to anthropic influences [7]. Hence, the advances in analytical techniques facilitate the application of the hydrochemical fingerprint concept. Inductively coupled plasmamass spectrometry (ICP-MS) is particularly suitable for this purpose due to the possibility of rapid multi-element analysis in combination with excellent detection limits [8-11]. The ICP-MS allows one to obtain complete information on the trace elements occurring in water, in- 
cluding those present in sub-ppb concentrations. The analytical capability of ICP-MS in this field has led to consideration of this technique for routine water analysis.

Several studies have shown that wells in areas with particular geological features yield water that does not meet established drinking water norms without any influence from anthropogenic contamination e.g. Misund et al., 1999 [7]; Frengstad et al., 2000 [12], Reimann et al. 2003 [13]. This work is a continuation of a previous work where heavy metal contamination of the groundwater of south West Bank in Palestine was assessed by analysis of different heavy metals $(\mathrm{Tl}, \mathrm{Pb}, \mathrm{Bi}, \mathrm{Cr}, \mathrm{Mn}, \mathrm{Co}, \mathrm{Ni}, \mathrm{Cu}$, $\mathrm{Zn}, \mathrm{Mo}, \mathrm{Al}, \mathrm{Ag}$, and $\mathrm{Cd}$ ) and results showed that $93 \%$ of all samples analyzed contained one or more of the 13 metals studied each in varying concentration, and some metals $(\mathrm{Pb} \mathrm{Cd}$, and $\mathrm{Al})$ are found to be higher than the allowed WHO limits in some samples. The present paper reports analytical results for some rare elements $(\mathrm{Rb}, \mathrm{Zr}$, $\mathrm{U}, \mathrm{P}, \mathrm{Ti}, \mathrm{V}, \mathrm{La}, \mathrm{Ce}$, and $\mathrm{Nd}$ ) as well as other common elements ( $\mathrm{Ca}, \mathrm{Mg}, \mathrm{K}, \mathrm{Sr}, \mathrm{Ba}$, and $\mathrm{Bi}$ ) which most of them have no maximum allowed concentrations by WHO or any other regulation agencies. The current study also document that quite a number of elements for which no drinking water guideline values or maximum acceptable concentration limits have been established can occur at unpleasantly high levels in natural well waters (e.g. Li, $\mathrm{Na}, \mathrm{Mg}, \mathrm{Ca}, \mathrm{Sr}, \mathrm{Ba}, \mathrm{K}, \mathrm{Bi}$ ).

\section{Experimental}

\subsection{Study Area}

West Bank is divided into eleven districts: Bethlehem, Hebron, Jenin, Jericho, Jerusalem, Nablus, Qalqilya, Ramallah and Al-Bireh, Salfit, Tubas, and Tulkarm. The districts are sub-divided into 89 municipalities, and there are local councils that manage all infrastructure and basic services in the towns and villages.

\subsubsection{Geography and Geology}

South of West Bank including Jerusalem, Beitlehem, and Hebron have a highly varying topography and altitude; with the highest point at $1011 \mathrm{~m}$ above sea level and the lowest at $150 \mathrm{~m}$ above sea level. In terms of geology, the majority of the study area is rocky mainly comprised of carbonate sediment such as limestone, chalky limestone and dolomite with marl. The geological rock age formations range from Turonian to Upper Cenomanian [14].

\subsubsection{Climate}

Water samples were obtained from south of West Bank/ Palestine including three areas: Jerusalem, Beitlehem, and Hebron. The climate of the study area ranges from arid to semi-arid with an increase in aridity towards the Negev desert in the south and the Jordan valley in the east. The monthly average temperature of the study area ranges from $7.5^{\circ} \mathrm{C}-10^{\circ} \mathrm{C}$ in the winter to $22^{\circ} \mathrm{C}$ in the summer. The minimum temperature is $-3^{\circ} \mathrm{C}$ in January and the maximum is $40^{\circ} \mathrm{C}$ in August. Most of the rain falls during December through February, although there may be rain from mid-October to the end of April. Water shortage is a serious problem facing the study area due to the arid and semi-arid climatic conditions [14].

\subsubsection{Groundwater: Aquifers and Wells}

The West Bank lies over the Mountain aquifer which is divided into the eastern aquifer, the northeastern aquifer, and the western aquifer. The eastern aquifer and part of the northeastern aquifer flow east towards the Jordan River. The western aquifer and part of the northeastern aquifer flow westerly towards the Mediterranean Sea [15, $16]$. In the study area, there are 24 wells [17].

\subsection{Sampling and Analysis}

Ten groundwater wells were selected as representative wells of the study area. Figure 1 shows location of the wells in the study area analyzed in this study. Three samples were obtained from each well. The selected wells were sampled three times in three different dates of 2012 and 2013 (November 2012, March 2013, and April 2013). A total of 90 water samples were collected from the ten wells. The water samples were collected in 1-liter high density polyethylene bottles (pre-cleaned with $10 \%$ nitric acid followed by repeated rinsing with bi-distilled water), stabilized with ultrapure nitric acid $\left(0.5 \% \mathrm{HNO}_{3}\right)$, preserved in a cool place (about $4^{\circ} \mathrm{C}$ ) and transported to the lab of Al-Quds University for further analysis. The samples were then analyzed for trace elements content by ICP/MS (Agilent technologies 7500 series).

For accurate quantitative determination of trace metals in water samples, an internal standard method was used using $\mathrm{Y}$ as internal standard and a multi-standard calibration method: (22 metals standard (Ag 10 ppm, Al 50 ppm, B 50 ppm, Ba 10 ppm, Bi 100 ppm, Ca 10 ppm, Cd 10 ppm, Co 10 ppm, Cr 50 ppm, Cu 10 ppm, Fe 10 ppm, K $100 \mathrm{ppm}$, Li 50 ppm, Mg $10 \mathrm{ppm}$, Mn $10 \mathrm{ppm}$, Mo 50 ppm, Na 50 ppm, Ni 50 ppm, Pb 100 ppm, Sr 10 ppm, Tl $50 \mathrm{ppm}, \mathrm{Zn} 10 \mathrm{ppm}$, matrix $5 \% \mathrm{HNO}_{3}$ ). Other standards containing $\mathrm{Rb}, \mathrm{Zr}, \mathrm{U}, \mathrm{P}, \mathrm{Ti}, \mathrm{V}, \mathrm{La}, \mathrm{Ce}, \mathrm{Nd}$ with concentration of $1000 \mathrm{ppm}$ in $5 \% \mathrm{HNO}_{3}$ solution. Samples were prepared by dilution of $1.0 \mathrm{~mL}$ of the water samples to $10.0 \mathrm{~mL}$ with $0.3 \%$ ultrapure nitric acid and analyzed by ICP/MS. Each sample was analyzed three times and the results are expressed as mean $\pm \mathrm{SD}$ (SD: standard deviation). Relative standard deviation (RSD) of the three results are calculated and found to be less than $5 \%$ for all samples for all metals analyzed in this study, reflecting 


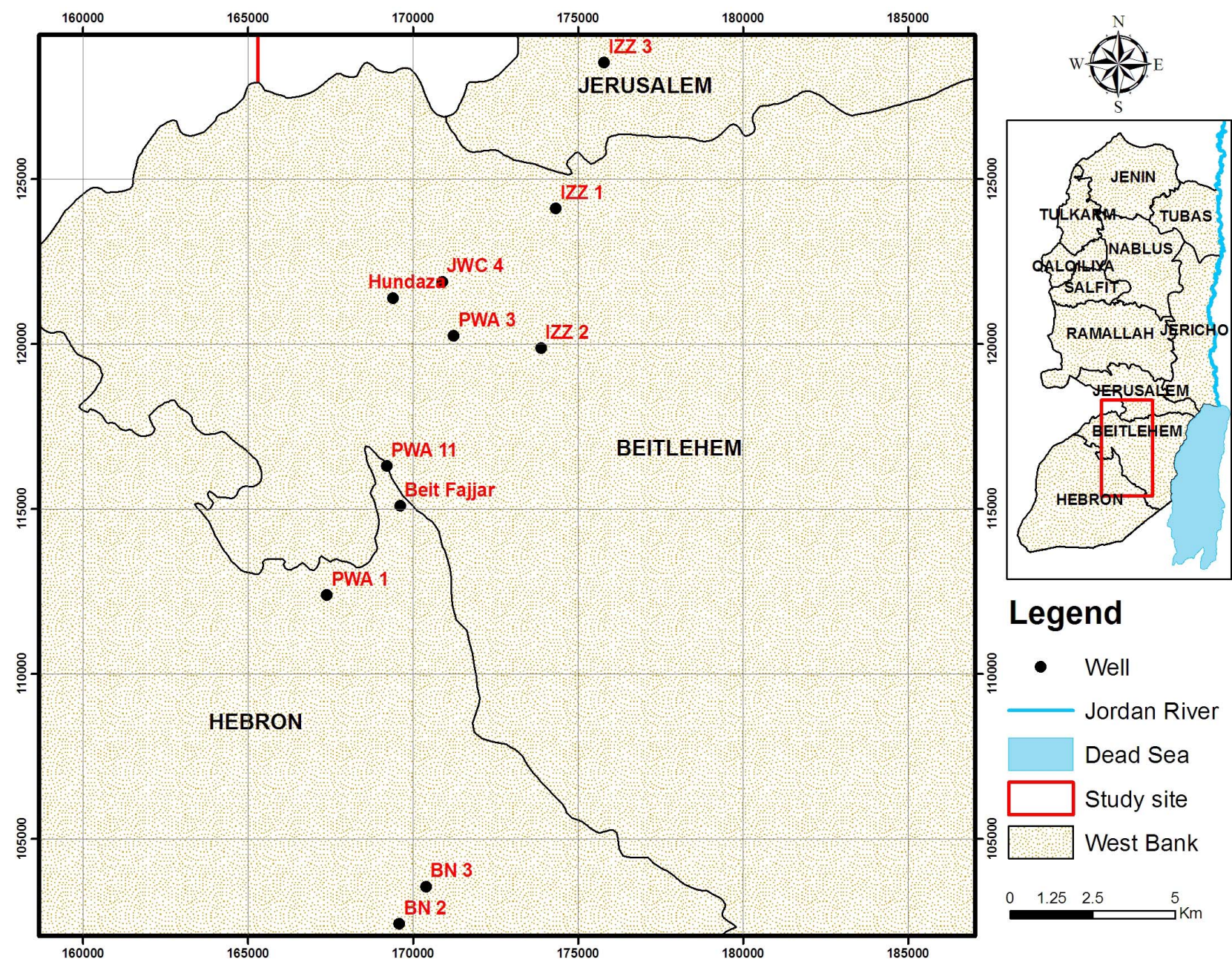

Figure 1. Map of West Bank and the study area showing location of the ground wells analyzed in this study.

the precision of the method for the analysis of these heavy metals. Calibration curves for all metals analyzed were constructed by plotting the ratio of the intensity of the analyte metal to that of the internal standard (Y) vs. concentration of the trace metal (in ppb), and results showed that the calibration curves are linear with correlation coefficient $\left(\mathrm{r}^{2}\right)$ greater than 0.999 for the trace metals analyzed.

The Agilent Technologies 7500 Series ICP-MS (Agilent 7500) can measure trace elements as low as one part per trillion (ppt) and quickly scan more than 70 elements to determine the composition of an unknown sample with a MassHunter Workstation software automates the analysis and accurately interprets the resulting data. The ICP/MS instrument consists of an on-board peristaltic pump that controls the flow of sample solution into and waste (drain) out of the instrument, a nebulizer (Micro Mist nebulizer) that uses a stream of argon to disperse the sample, an ICP Argon plasma torch using Argon as plasma gas, auxillary gas and nebulizer (carrier) gas, two pumps for evacuation, quadrupole mass analyzer with $0.8 \mathrm{amu}$ resolution at $10 \%$ height, an octapole reaction system (ORS), and electron multiplier detector.

The operating conditions are as follows: nebulizer gas (argon) flow rate: $0.9 \mathrm{~L} / \mathrm{min}$, auxiliary gas (argon) flow $0.3 \mathrm{~L} / \mathrm{min}$, plasma (Argon) gas flow: $15 \mathrm{~L} / \mathrm{min}$, reaction gas flow (helium) $4 \mathrm{~mL} / \mathrm{min}$, lens voltage $7.25 \mathrm{~V}$, ICP RF power: $1100 \mathrm{~W}, \mathrm{CeO} / \mathrm{Ce}=1 \%$, and $\mathrm{Ce}^{+2} / \mathrm{Ce}^{+1}=1 \%$.

\subsection{Statistical Analysis}

Data were analyzed using Origin 9 software. Statistical differences were tested using one way ANOVA. Differences were considered significant at $\mathrm{p}$ values $\leq 0.05$.

\section{Results and Discussion}

\subsection{Concentration of the Analyzed Elements}

\subsubsection{Rare Elements}

The detection limits of the studied elements are reported 
in Table 1, and are three times the standard deviation estimated from six replicate measurements of the blank $\left(1 \% \mathrm{v} / \mathrm{v} \mathrm{HNO}_{3}\right)$. The detection limits by ICP-MS range between 0.01 and $8.0 \mathrm{ppb}$ for the trace elements analyzed in this study. Table 1 summarizes concentrations (minimum, median, maximum, average, and standard deviation) of the trace elements ( $\mathrm{Li}, \mathrm{Na}, \mathrm{Mg}, \mathrm{Ca}, \mathrm{Sr}, \mathrm{Ba}, \mathrm{Bi}, \mathrm{K}$ which are analyzed on November 2012, March 2013 and April 2013) as well as rare elements ( $\mathrm{Rb}, \mathrm{Zr}, \mathrm{La}, \mathrm{Ce}, \mathrm{Nd}$, U, P, Ti, V which are analyzed in April 2013) for the groundwater samples analyzed in this study. It provides additional information on water standards (WHO, European Union, US EPA) for some elements analyzed in this study ( $\mathrm{Na}, \mathrm{Ba}, \mathrm{U}$, and $\mathrm{Sr})$. One of the largest differences in opinion between the authorities exists for $\mathrm{U}$, for which the EU has not defined any maximum acceptable limit, while WHO (1998) has set a limit of $2 \mathrm{ppb}$, based on toxicological considerations [18]. The concentration of $\mathrm{U}$ in the water samples for the 10 ground wells analyzed in this study was found to be in the range of 0.81 to 1.48 ppb with a median of 0.94 and average of $0.98 \mathrm{ppb}$. Although all water samples have $\mathrm{U}$ within the acceptable limits, it has been detected in all samples analyzed in this study. Uranium is present in the environment as a result of leaching from natural deposits, release in mill tailings, emissions from the nuclear industry, the combustion of coal and other fuels and the use of phosphate fertilizers that contain uranium. Its presence in drinking water is most commonly from natural sources. Uranium occurrence in groundwater has been already reported in many

Table 1. Concentration (in ppb) of different elements detected in groundwater wells analyzed in this study.

\begin{tabular}{|c|c|c|c|c|c|c|c|c|}
\hline Element & $\begin{array}{l}\text { LOD } \\
(\mathrm{ppb})\end{array}$ & Sampling date & $\underset{(\mathrm{ppb})}{\operatorname{Minimum}}$ & $\begin{array}{l}\text { Median } \\
(\mathrm{ppb})\end{array}$ & $\underset{(\mathrm{ppb})}{\operatorname{Maximum}}$ & $\begin{array}{l}\text { Average } \\
(\mathrm{ppb})\end{array}$ & SD & Limits \\
\hline \multirow{3}{*}{$\mathrm{Li}$} & \multirow{3}{*}{0.1} & November 2012 & 0.7 & 2.10 & 3.50 & 2.06 & 0.84 & \multirow{3}{*}{ No limits } \\
\hline & & March 2013 & 0.99 & 2.33 & 12.4 & 3.17 & 2.91 & \\
\hline & & April 2013 & 1.09 & 1.86 & 5.31 & 2.32 & 1.29 & \\
\hline \multirow{3}{*}{$\mathrm{Na}$} & \multirow{3}{*}{3} & November 2012 & 115.4 & 138.0 & 183.1 & 139.1 & 19.6 & \multirow{3}{*}{$\begin{array}{l}200 \mathrm{ppm} \text { (EU Directive). } \\
{ }^{*} 20 \mathrm{ppm} \text { (desirable limit according to WHO 2004). }\end{array}$} \\
\hline & & March 2013 & 157.1 & 339.5 & 577.7 & 356.5 & 104.0 & \\
\hline & & April 2013 & 24405 & 21112 & 57302 & 21011 & 13224 & \\
\hline \multirow{3}{*}{$\mathrm{Mg}$} & \multirow{3}{*}{5} & November 2012 & 396.0 & 487.4 & 581.3 & 480.9 & 59.2 & \multirow{3}{*}{ No limits } \\
\hline & & March 2013 & 198.4 & 6376.7 & 7459.0 & 5864.5 & 1800.0 & \\
\hline & & April 2013 & 21708 & 26123 & 32211 & 26001 & 2501 & \\
\hline \multirow{3}{*}{$\mathrm{Ca}$} & \multirow{3}{*}{5} & November 2012 & 71.0 & 99.3 & 121.6 & 96.9 & 15.4 & \multirow{3}{*}{ No limits } \\
\hline & & March 2013 & 164.7 & 590.2 & 717.7 & 555.7 & 134.4 & \\
\hline & & April 2013 & 9901 & 11405 & 13308 & 11621 & 1011 & \\
\hline \multirow{3}{*}{$\mathrm{Sr}$} & \multirow{3}{*}{1} & November 2012 & 74.6 & 232.6 & 831.6 & 349.8 & 241.7 & \multirow{3}{*}{4 ppm (U.S. EPA) } \\
\hline & & March 2013 & 147.3 & 283.4 & 623.6 & 327.8 & 173.7 & \\
\hline & & April 2013 & 189.8 & 272.0 & 720.9 & 376.7 & 204.4 & \\
\hline \multirow{3}{*}{$\mathrm{Ba}$} & \multirow{3}{*}{1.0} & November 2012 & 43.6 & 81.8 & 165.9 & 99.4 & 44.1 & \multirow{3}{*}{700 ppb (WHO) } \\
\hline & & March 2013 & 7.2 & 16.53 & 58.5 & 19.14 & 13.97 & \\
\hline & & April 2013 & 21.6 & 49.8 & 65.9 & 45.8 & 13.8 & \\
\hline \multirow{3}{*}{$\mathrm{Bi}$} & \multirow{3}{*}{0.01} & November 2012 & 3.41 & 18.20 & 215.7 & 48.0 & 69.4 & \multirow{3}{*}{ No limits } \\
\hline & & March 2013 & 1.62 & 1.63 & 2.8 & 1.71 & 0.32 & \\
\hline & & April 2013 & 0.02 & 0.16 & 1.10 & 0.33 & 0.45 & \\
\hline \multirow{3}{*}{$\mathrm{K}$} & \multirow{3}{*}{8.0} & November 2012 & 194.0 & 248.3 & 311.6 & 247.7 & 40.0 & \multirow{3}{*}{ No limits } \\
\hline & & March 2013 & 903.6 & 1227.1 & 1789.1 & 1216.6 & 229.0 & \\
\hline & & April 2013 & 1305 & 1612 & 2914 & 1721 & 460 & \\
\hline $\mathrm{Rb}$ & 0.01 & April 2013 & 0.28 & 0.59 & 1.0 & 0.61 & 0.20 & No limits \\
\hline $\mathrm{Zr}$ & 0.01 & April 2013 & 0.02 & 0.11 & 1.13 & 0.30 & 0.36 & No limits \\
\hline $\mathrm{La}$ & 0.01 & April 2013 & 0.01 & 0.01 & 0.02 & 0.01 & 0.007 & No limits \\
\hline $\mathrm{Ce}$ & 0.01 & April 2013 & 0.02 & 0.05 & 0.09 & 0.05 & 0.03 & No limits \\
\hline $\mathrm{Nd}$ & 0.01 & April 2013 & 0.01 & 0.01 & 0.03 & 0.01 & 0.01 & No limits \\
\hline $\mathrm{U}$ & 0.001 & April 2013 & 0.81 & 0.94 & 1.48 & 0.98 & 0.20 & $2 \mathrm{ppb}$ (WHO) \\
\hline $\mathrm{P}$ & 0.1 & April 2013 & 0.31 & 6.15 & 9.66 & 5.70 & 2.9 & No limits \\
\hline $\mathrm{Ti}$ & 0.02 & April 2013 & 0.09 & 0.19 & 0.32 & 0.21 & 0.08 & No limits \\
\hline $\mathrm{V}$ & 0.03 & April 2013 & 1.90 & 3.28 & 4.99 & 3.34 & 1.04 & No limits \\
\hline
\end{tabular}


regions; in a survey of 130 sites (approximately 3700 samples) in Ontario, Canada, conducted between 1990 and 1995, the mean of the average uranium concentrations (range $0.05-4.21 \mu \mathrm{g} /$ litre) in treated drinking-water was $0.40 \mathrm{ppb}$ [19]. A study in Finland examined a population receiving drinking-water containing uranium with a median concentration of $28 \mathrm{ppb}$ [20]. In a study of 476 Norwegian groundwater samples, $18 \%$ had uranium concentrations in excess of $20 \mathrm{ppb}$ [12]. Concentrations in excess of $20 \mathrm{ppb}$ have been reported in groundwater from parts of New Mexico, USA [21], and central Australia [22]. Intake through drinking-water is normally low; however, in circumstances in which uranium in present in a drinking-water source, the majority of intake can be through drinking-water [23].

No drinking water standards are defined by EU, WHO or US EPA for Rb, Zr, La, Ce, Nd, P, Ti, and V. Several of these elements have documented health effects [13]. For others, for example the rare earth elements, knowledge about health effects are rather limited [24]. However all of these elements are detected in all groundwater samples analyzed in this study. Additionally, some of these elements are unexpectedly and surprisingly detected with high concentrations e.g. $\mathrm{P}, \mathrm{V}$; the concentration of $\mathrm{P}$ ranges from 0.31 to $9.66 \mathrm{ppb}$ with an average of $5.70 \mathrm{ppb}$, and the concentration of $\mathrm{V}$ ranges from 1.90 to $4.99 \mathrm{ppb}$ with an average of $3.34 \mathrm{ppb}$. The concentration of $\mathrm{Rb}, \mathrm{Zr}$, $\mathrm{La}, \mathrm{Ce}, \mathrm{Nd}$, and $\mathrm{Ti}$ was found to be in the range of 0.28 1.0 (average $=0.61 \mathrm{ppb}), 0.02-1.13$ (average $=0.30$ ppb), $0.01-0.02$ (average $=0.01 \mathrm{ppb}), 0.02-0.09$ (average $=0.05 \mathrm{ppb}), 0.01-0.03($ average $=0.01 \mathrm{ppb}), 0.09$ - 0.32 (average $=0.21 \mathrm{ppb}$ ), respectively. In addition to the potential pollution of groundwater with these rare elements, the concentrations of these elements such $\mathrm{Bi}$, and rare earth elements, which are extremely low in natural waters, are of particular interest to fingerprint the groundwater sources [25].

\subsubsection{Common Elements}

Concerning $\mathrm{Na}, \mathrm{Mg}, \mathrm{Ca}, \mathrm{Sr}$, and $\mathrm{Li}$, they are elements of primarily geogenic origin. Their presence in groundwater is due to rock-water interaction over time and/or weathering of silicate and carbonate minerals in particular [13]. Of these elements, only sodium and strontium has maximum acceptable limits, while the rest $(\mathrm{Mg}, \mathrm{Ca}$, and $\mathrm{Li})$ have no limits. However, several of the elements that have no maximum allowed limits in drinking water are deemed to have health effects [13]. Furthermore, there are a number of elements that are rather toxic and/or carcinogenic for which no maximum allowed limit has been defined, probably often under the assumption that "natural concentrations in water must be very low" (WHO, 1993; statement with regard to $\mathrm{Be}$ ) [26]. Our results showed that the concentrations of some elements analyzed cover between one and three orders of magnitude. For many of these elements, little is known about health effects at drinking water concentrations. In this respect, it is important to analyze and monitor regularly such elements that have no maximum acceptable limits in drinking water.

Sodium exists in ground water naturally as a result of rock-water interactions. Sodium ion is ubiquitous in water, owing to the high solubility of its salts and the abundance of Na-containing mineral deposits [27]. According to WHO 2004 [28], the desirable limit of sodium is 20 ppm, while the limit is 200 ppm according to EU Directive regulations [29]. Our results showed that the concentration of sodium ranges from $0.12-0.18$ (average is $0.14 \mathrm{ppm}$ ), $0.16-0.58$ (average is $0.36 \mathrm{ppm}$ ), $24.4-57.3$ (average is $21.0 \mathrm{ppm}$ ) for the water samples analyzed in November 2012, March 2013, and April 2013, respectively. These results show that all water samples collected in April 2013 exceeded the desirable limit of $\mathrm{Na}$ according to WHO 2004 (20 ppm) while this concentration is still within the limit of EU directive (200 ppm). Anyway, the concentration of sodium in ground water collected in April 2013 is relatively large which indicates that groundwater of the study area needs regular monitoring. Although sodium is essential to human body, excessive intake or very high doses of $\mathrm{Na}$ may cause acute effects such as nausea, vomiting, inflammatory reaction in the gastrointestinal tract, thirst, muscular twitching, and convulsions. For long-term lower level exposures, the health effect of primary concern is hypertension, central nervous system disturbances such as convulsions, confusion and pulmonary edema are possible [27]. Magnesium is present also naturally in ground water. There is no limit for $\mathrm{Mg}$ according to $\mathrm{WHO}$ or EU. However, regulative agencies in some countries set a limit for $\mathrm{Mg}$. For example, the Bureau of Indian Standards (BIS) has set a limit of $30 \mathrm{ppm}$ for $\mathrm{Mg}$ in drinking water [30]. As in the case of $\mathrm{Na}$, the concentration of $\mathrm{Mg}$ in the ground water samples collected in April 2013 is high (21.7 - 32.2 ppm) and exceeded the limit of BIS for $\mathrm{Mg}$ in drinking water $(30 \mathrm{ppm})$ for some groundwater samples (more than $60 \%$ of the analyzed water samples). Increased intake of $\mathrm{Mg}$ salts may cause a change in bowel habits (diarrhea), but seldom causes hypermagnesemia in persons with normal kidney function. Excess $\mathrm{Mg}$ concentration may lead to changes in mental status, nausea, diarrhea, loss of appetite, muscle weakness, difficulty in breathing, extremely low blood pressure, and irregular heartbeat [31].

The concentration of calcium, which present naturally in ground water, was found to be in the range of 9.9 $13.3 \mathrm{ppm}$ with an average of $11.6 \mathrm{ppm}$ in April 2013, while its concentration in November 2012 and March 
2013 is low (less than $1 \mathrm{ppm}$ ). The desirable limit of $\mathrm{Ca}$ is specified as $75 \mathrm{ppm}$ for drinking water according to WHO [32]. Concern for excess calcium intake is directed primarily to those who are prone to milk alkali syndrome (the simultaneous presence of hypercalcemia, metabolic alkalosis and renal insufficiency) and hypercalcemia. Although calcium can interact with iron, zinc, magnesium and phosphorous within the intestine, thereby reducing the absorption of these minerals, available data do not suggest that these minerals are depleted when humans consume diets containing calcium above the recommended levels [32]. Water hardness has been related with cardiovascular diseases, though it is not clear whether it is due to calcium and/or magnesium or because metals are more soluble in hard waters [33]. Strontium which behaves chemically like calcium has a geogenic origin, so it present naturally in ground water. The concentration of Strontium in the 90 ground water samples analyzed in this study was found to be in the range of 74.6 - 831.6 (average is $349.8 \mathrm{ppb}$ ), 147.3 - 623.6 (average is $327.8 \mathrm{ppb}$ ), and 189.8 - 720.9 (average $376.7 \mathrm{ppb}$ ) for water samples collected in November 2012, March 2013, and April 2013, respectively. The US Environmental Protection Agency (EPA) has developed a limit of $4 \mathrm{ppm}$ for strontium levels in drinking water [34]. However WHO does not set a maximum acceptable limit of $\mathrm{Sr}$ in drinking water. According to EPA, Water that contains more than $4 \mathrm{ppm}$ of $\mathrm{Sr}$ should not be used for drinking water or to prepare beverages, food with water as a major ingredient or infant formulas. Lithium which exist in the groundwater naturally was found to be in the ground water samples analyzed in this study in the range of $0.70-3.5,0.99$ 12.4 , and $1.09-5.31 \mathrm{ppb}$ for the samples analyzed in November 2012, March 2013, and April 2013, respectively. There is no maximum acceptable limit of $\mathrm{Li}$ in drinking water.

Regarding the concentration of potassium in the ground water samples analyzed in this study, it ranges from 194.0 to $311.6 \mathrm{ppb}$ (with an average of $247.7 \mathrm{ppb}$ ), 903.6 to $1789.1 \mathrm{ppb}$ (average of $1216.6 \mathrm{ppb}$ ), and 1305.3 to $2914.6 \mathrm{ppb}$ (average 1721.3 ppb) for water samples collected in November 2012, March 2013, and April 2013, respectively. There is no limit for $\mathrm{K}$ in drinking water according to WHO or EPA.

However, increased exposure to potassium could result in significant health effects in people with kidney disease or other conditions, such as heart disease, coronary artery disease, hypertension, diabetes, adrenal insufficiency and pre-existing hyperkalemia. Symptoms of hyperkalemia include weak pulse rate, irregular heartbeat and nausea [35]. Infants have also a limited renal reserve and imamture kidney function and may therefore be morevulnerable [36]. The concentration of Barium in the ground water samples analyzed in this study was found to be in the range of 43.6 to $165.9 \mathrm{ppb}$ ( with an average of 99.4 $\mathrm{ppb}$ ), 7.2 to $58.5 \mathrm{ppb}$ (average of $19.14 \mathrm{ppb}$ ), and 21.6 to $65.9 \mathrm{ppb}$ (average $45.8 \mathrm{ppb}$ ) for water samples collected in November 2012, March 2013, and April 2013, respect tively. WHO has set a maximum allowed limit for $\mathrm{Ba}$ in drinking water of $700 \mathrm{ppb}$ [18]. Ba in drinking-water is likely to be associated with groundwater of low $\mathrm{pH}$ from granite-like igneous rocks, alkaline igneous and volcanic rocks and manganese-rich sedimentary rocks. Concentrations are, therefore, expected to be relatively stable [37]. When people are exposed to Ba for short periods at levels above the maximum contaminant level, they may experience gastrointestinal disturbances and muscular weakness. Additionally, $\mathrm{Ba}$ has the potential to cause high blood pressure when exposed to levels above the limit for long periods of time [37]. Concerning the concentration of Bismuth in the ground water samples analyzed in this study, our results showed that the it ranges from 3.41 to $215.71 \mathrm{ppb}$ (with an average of $48.02 \mathrm{ppb}$ ), 1.62 to 2.82 ppb (average of $1.71 \mathrm{ppb}$ ), and 0.02 to $1.10 \mathrm{ppb}$ (average $0.33 \mathrm{ppb}$ ) for water samples collected in November 2012, March 2013, and April 2013, respectively. Although there are no limits for $\mathrm{Bi}$ in drinking water by WHO, EPA or any other agency, it has been detected in all water samples analyzed in this study.

\subsection{Effect of Sampling Date on the Content of the Analyzed Elements}

Statistical analyses were conducted to test if there is significant difference in the concentration of the studied elements in the groundwater wells as a function of the sampling date (November 2012, March 2013, and April 2013), and results confirmed that there is a significant difference, denoting that element concentration in the wells vary significantly with sampling time. As it is seen in Table 1, the highest concentration of $\mathrm{Li}$ varies from $3.5 \mathrm{ppb}$ in November 2012 to $12.4 \mathrm{ppb}$ in March 2013. For $\mathrm{Na}, \mathrm{Mg}, \mathrm{Ca}$, the concentration increases significantly from November 2012 through March 2013 and April 2013. For example, the highest concentration of $\mathrm{Na}$ increases from 0.18 in November 2012 to $57.3 \mathrm{ppm}$ in April 2013. The same applies for $\mathrm{Mg}$ and $\mathrm{Ca}$ where the highest concentration increases from 0.58 to 32.2 (for $\mathrm{Mg}$ ), and from 0.12 to $13.3 \mathrm{ppm}$ (for $\mathrm{Ca}$ ). For $\mathrm{K}$, the same applies where the highest and lowest concentration increases from November 2012 to April 2013, see Table 1. The reverse is observed for $\mathrm{Bi}$ where the highest and lowest concentration decreases in going from November 2012 to April 2013 (see Table 1), for example the highest concentration was $215.7 \mathrm{ppb}$ in November 2012 while it decreases to $1.10 \mathrm{ppb}$ in April 2013 (about 196 fold). For $\mathrm{Sr}$ and $\mathrm{Ba}$, there are fluctuations in their concentra- 
tion with significant variations. For $\mathrm{Ba}$, the highest concentration in November 2012 is 165.9 while it is 58.5 $\mathrm{ppb}$ in March 2013. For Sr, the highest concentration was found to be $831.6 \mathrm{ppb}$ in November 2012 while it is $623.6 \mathrm{ppb}$ in March 2013.

\section{Conclusion}

High concentrations are observed for a number of elements for which no maximum allowed concentration values have been proposed (e.g., Li, Sr, Bi, Ba, V). These elements may warrant a toxicological assessment. These elements need urgent attention from a health perspective. Public authorities might be well advised to establish maximum allowed limits for such elements. This study demonstrates the necessity of documenting natural element concentrations and variation in drinking water resources on a regional scale. This must be carried out for as many elements as can be analyzed with today's techniques in different geological settings, to provide fingerprints of the different types of water.

\section{Acknowledgements}

The authors are grateful for the German research funding organisation (Deutsche Forschungsgemeinschaft), DFG for their financial support through TRION project.

\section{REFERENCES}

[1] EU (European Union) Directive $98 / 83 / \mathrm{EC}$ on the Quality of Water intended for Human Consumption. OJ, L330, December 1998.

[2] D. Banks, A. K. Midtgard, G. Morland, C. Reimann, T. Strand, K. Bjorvatn and U. Siewers, "Is Pure Groundwater Safe to Drink? Natural 'Contamination' of Groundwater in Norway," Geology Today, Vol. 14, No. 3, 1998, pp. 104-113. http://dx.doi.org/10.1046/j.1365-2451.1998.014003104.x

[3] B. T. Hart and T. Hines, "Trace Elements in Rivers," In: B. Salbu and E. Steinnes, Eds., Trace Elements in Natural Waters, CRC Press, Boca Raton, 1995, pp. 203-221.

[4] C. Reimann, G. E. M. Hall, U. Siewers, K. Bjorvatn, G. Morland, H. Skarphagen and T. Strand, "Radon, Fluoride and 62 Elements as Determined by ICP-MS in 145 Norwegian Hard Rock Groundwater Samples," Science Total Environment, Vol. 192, No. 1, 1996, pp. 1-19. http://dx.doi.org/10.1016/0048-9697(96)05272-2

[5] C. Reimann, U. Siwers, H. Skarphagen and D. Banks "Influence of Filtration on Concentrations of 62 Elements Analysed on Crystalline Bedrock Groundwater by ICPMS," Science Total Environment, Vol. 234, No. 1-3, 1999 , pp. 155-173. http://dx.doi.org/10.1016/S0048-9697(99)00165-5

[6] S. Hesske, A. Parriaux and M. Bensimon, "Geochemistry of Spring Waters in Molasse Aquifers: Typical Mineral Trace Elements," Eclogae Geologicae Helvetiae, Vol. 90,
No. 1, 1997, pp. 151-171.

[7] A. Misund, B. Frengstad, U. Siewers and C. Reimann, "Natural Variation of 66 Elements in European Mineral Waters," Science Total Environment, Vol. 243, No. 244, 1999, pp. 21-41.

http://dx.doi.org/10.1016/S0048-9697(99)00307-1

[8] I. Kim and G. Kim, "Large Fluxes of Rare Earth Elements through Submarine Groundwater Discharge (SGD) from a Volcanic Island, Jeju, Korea," Marine Chemistry, Vol. 127, No. 1-4, 2011, pp. 12-19. http://dx.doi.org/10.1016/j.marchem.2011.07.006

[9] R. P. Janssen and W. Verweij, "Geochemistry of Some Rare Earth Elements in Groundwater, Vierlingsbeek, The Netherlands," Water Research, Vol. 37, No. 6, 2003, pp. 1320-1350. http://dx.doi.org/10.1016/S0043-1354(02)00492-X

[10] G. G. Gruau, A. Dia, G. Olivie-Lauquet, M. Davranche and G. Pinay, "Controls on the Distribution of Rare Earth Elements in Shallow Groundwaters," Water Research, Vol. 38, No. 16, 2004, pp. 3576-3586. http://dx.doi.org/10.1016/j.watres.2004.04.056

[11] M. A. Rasheed, B. A. Radha, P. L. Srinivasa Rao, M. Lakshmi, J. Bala Chennaiah and A. M. Dayal, "Evaluation of Potable Groundwater Quality in Some Villages of Adilabad in Andhra Pradesh, India," Journal of Environmental Biolog, Vol. 33, 2012, pp. 689-693.

[12] B. Frengstad, A. K. Midtgard, D. Banks, J. R. Krog and U. Siewers, "The Chemistry of Norwegian Groundwaters. III. The Distribution of Trace Elements in 476 Crystalline Bedrock Groundwaters as Analysed by ICP-MS Techniques," Science of the Total Environment, Vol. 246, No. 1, 2000, pp. 21-40. http://dx.doi.org/10.1016/S0048-9697(99)00413-1

[13] C. Reimanna, K. Bjorvatnb, B. Frengstada, Z. Melakuc, R. Tekle-Haimanotc and U. Siewersd, "Drinking Water Quality in the Ethiopian Section of the East African Rift Valley I-Data and Health Aspects," The Science of the Total Environment, Vol. 311, No. 1-3, 2003, pp. 65-80. http://dx.doi.org/10.1016/S0048-9697(03)00137-2

[14] "Environmental Profile for the West Bank, Volume 3: Hebron District," Applied Research Institute, Jerusalem, 1995.

[15] A. Abed and S. Wishahi, "Geology of Palestine: The West Bank and Gaza Strip. Palestine," Palestine Hydrology Group, 1999.

[16] F. M. Anayah and M. N. Almasri, "Trends and Occurrences of Nitrate in the Groundwater of the West Bank, Palestine," Applied Geography, Vol. 29, No. 4, 2009, pp. 588-601. http://dx.doi.org/10.1016/j.apgeog.2009.01.004

[17] PHG, "Water For Life," Water, Sanitation and Hygiene Monitoring Program (WaSH MP), 2007/2008.

[18] WHO, "Guidelines for Drinking-Water Quality, Addendum to Vol. 1. Recommendations," 2nd Edition, World Health Organisation, Geneva, 1998, pp. 10-11.

[19] OMEE, "Monitoring Data for Uranium-1990-1995. Toronto, Ontario," Ontario Ministry of Environment and Energy, Ontario Drinking Water Surveillance Program, 
1996.

[20] P. Kurttio, A. Auvinen, L. Salonen, H. Saha, J. Pekkanen, I. Makeläinen, S. B. Vaisanen, I. M. Penttila and H. Komulainen, "Renal Effects of Uranium in Drinking Water," Environmental Health Perspectives, Vol. 110, No. 4, 2002, pp. 337-342. http://dx.doi.org/10.1289/ehp.02110337

[21] A. C. Hakonson-Hayes, P. R. Fresquez and F. W. Whicker, "Assessing Potential Risks from Exposure to Natural Uranium in Well Water," Journal of Environmental Radioactivity, Vol. 59, No. 1, 2002, pp. 29-40. http://dx.doi.org/10.1016/S0265-931X(01)00034-0

[22] J. Fitzgerald, D. Cunliffe, S. Rainow, S. Dodds, S. Hostetler and G. Jacobson, "Groundwater Quality and Environmental Health Implications, Anangu Pitjantjatjara Lands, South Australia. Canberra," Bureau of Rural Sciences, 2000 .

[23] WHO, WHO/SDE/WSH/03.04/118/Rev/1, Background Document for Development of WHO Guidelines for Drinking Water Quality, 2012.

[24] S. Hirano and K. T. Suzuki, "Exposure, Metabolism, and Toxicity of Rare Earths and Related Compounds," Environ Health Perspective, Vol. 104, No. 1, 1996, pp. 85-95.

[25] P. L. Smedley and D. G. Kinniburgh, "A Review of the Source, Behavior and Distribution of Arsenic in Natural Waters," Applied Geochemistry, Vol. 17, No. 5, 2002, pp. 517-568. http://dx.doi.org/10.1016/S0883-2927(02)00018-5

[26] WHO, "Guidelines for Drinking Water Quality," World Health Organisation, Geneva, 1993.

[27] US EPA, "Consumer Factsheet on: Nitrates/Nitrites," 2003. http://www.epa.gov/safewater/dwh/c-ioc/nitrates.html

[28] WHO, "Guidelines for Drinking Water Quality," 3rd Edition, Vol. 1, Recommendations, Geneva, 2004.
[29] European Union, "Council Directive 98y83yEC of 3 November 1998 on the Quality of Water Intended for Human Consumption," Official Journal of the European Community, Vol. L330, 1998, pp. y32-y54.

[30] BIS (Bureau of Indian Standards), "Specification for Drinking Water, Indian Standard (IS: 10500)," New Delhi, 1993.

[31] T. H. Jaing, I. H. Hung, H. T. Chung, C. H. Lai, W. M. Liu and K. W. Chang, "Acute Hypermagnesemia: A Rare Complication of Antacid Administration after Bone Marrow Transplantation," Clinica Chimica Acta, Vol. 326, No. 1-2, 2002, pp. 201-203.

http://dx.doi.org/10.1016/S0009-8981(02)00308-X

[32] WHO, "Calcium and Magnesium in Drinking-Water: Public Health Significance," Library Cataloguing-in-Publication Data, Geneva, 2009.

[33] W. M. Edmunds and P. L. Smedley, "Groundwater Geochemistry and Health. Overview," In: J. D. Appleton, R. Fuge and J. G. H. Mc. Call, Eds., Enviromental Geochemistry and Health with Special Reference to Developing Countries, Geological Society, Special Publication, Vol. 113, 1996, pp. 91-105.

[34] US Environmental Protection Agency, "Strontium," 2012. http://www.epa.gov/rpdweb00/radionuclides/strontium.ht $\mathrm{ml}$

[35] J. L. Seifter, "Potassium Disorders," In: L. Goldman, D. Ausiello and C. Medi, Eds., Cecil Medicine, 23rd Edition, Chapter 118, Saunders Elsevier, Philadelphia, 2007.

[36] WHO, "Potassium in Drinking Water: Background Document for Development of WHO Guidelines for Drinking Water Quality," Geneva, 2009.

[37] WHO, "Barium in Drinking-Water Background Document for Development of WHO, Guidelines for DrinkingWater Quality," Geneva, 2004. 